\title{
miR-29a suppresses IL-13-induced cell invasion by inhibiting YY1 in the AKT pathway in lung adenocarcinoma A549 cells
}

\author{
YU ZHANG $^{1 *}$, SHUJIN HE $^{1 *}$, RENMEI MEI $^{1 *}$, YURONG KANG $^{1}$, JING DUAN $^{1}$, RAN WEI $^{1}$, \\ CHUQI XIANG ${ }^{1}$, YEMENG WU ${ }^{1}$, XIANGTONG LU ${ }^{1}$, ZHENYU CAI ${ }^{1}$ and LIXIA XIONG ${ }^{1,2}$ \\ ${ }^{1}$ Department of Pathophysiology, Medical College, Nanchang University; ${ }^{2}$ Jiangxi Province Key Laboratory of \\ Tumor Pathogenesis and Molecular Pathology, Nanchang, Jiangxi 330006, P.R. China
}

Received August 17, 2017; Accepted March 29, 2018

DOI: $10.3892 /$ or.2018.6352

\begin{abstract}
IL-13 is a proinflammatory cytokine associated with multiple pathological conditions and the promotion of metastasis in lung cancer. Previous studies have demonstrated that IL-13 and YY1 are associated with PI3K/AKT signaling. In addition, miR-29a has been found to play a critical role in cell invasion in lung cancer. However, the molecular mechanism of miR-29a underlying its involvement in IL-13-induced lung cancer cell invasion remains largely unknown. In the present study, we aimed to investigate the role of miR-29a in cell invasion mediated by IL-13 in lung cancer. By using MTT and wound-scratch assays, we assessed cell proliferation and migration induced by IL-13, and identified activation of the PI3K/AKT/YY1 pathway. Inhibition of PI3K/AKT by LY294002 downregulated IL-13-induced YY1 expression. Furthermore, we found that miR-29a directly targets YY1 and suppressed its expression in lung cancer. By using MTT, flow cytometry and Transwell assays, overexpression of miR-29a restricted both YY1 and N-cadherin expression, and inhibited IL-13-induced invasion of lung cancer A549 cells. Taken together, these findings demonstrate that PI3K/AKT/YY1 is involved in the regulation of lung cancer cell behavior induced by IL-13, and miR-29a represents a promising therapeutic target.
\end{abstract}

\section{Introduction}

Lung cancer is one of the most common cancers worldwide and is associated with increased morbidity and mortality. Most patients are diagnosed with lung cancer at the advanced and

Correspondence to: Dr Lixia Xiong, Department of Pathophysiology, Medical College, Nanchang University, 461 Bayi Road, Nanchang, Jiangxi 330006, P.R. China

E-mail: xionglixia@ncu.edu.cn

*Contributed equally

Key words: IL-13, lung adenocarcinoma, A549 cells, PI3K/AKT pathway, YY1, miR-29a non-curable stage since there are no obvious symptoms in the early stages. Exploring novel genes and epigenetic mechanisms that are involved in lung tumorigenesis and identification of potential targets or therapeutic interventions have become increasingly urgent in cancer research (1). Interleukin-13 (IL-13) is a proinflammatory cytokine which regulates immune responses and the microenvironment in cancer as well as orchestrating normal and abnormal cell behaviors $(2,3)$. The receptor subunits of IL-13, IL-13R $\alpha 1$ and IL-13R $\alpha 2$, are found to be overexpressed in many cancer types (4-7). Ying Yang 1 (YY1) is a member of the GLI-Krüppel family of transcription factors and is widely distributed in eukaryotic cells (8). YY1 activates the expression levels of other transcription factors such as $c-M y c$ by directly binding to their promoters and functions as an oncogene (9). Controversially, YY1 has been shown to inhibit cell proliferation in breast cancer, indicating its differential roles in different tissues. Previous reports have demonstrated that IL-13 and YY1 are associated with the PI3K/AKT signaling pathway (10-13). However, how IL-13 and YY1 regulate the PI3K/AKT pathway in lung cancer is currently unclear.

Recently, microRNAs (miRNAs) are found to be involved in every step of tumor progression, including proliferation, apoptosis, angiogenesis and metastasis (14). miRNAs are endogenous non-coding RNAs with short hairpin structures found in eukaryotes. They can complementarily bind with the 3'UTR region of target mRNAs, thus inhibiting mRNA translation and inducing mRNA degradation. miRNAs can function as oncogenes known as oncomiRs, and oncomiRs are found to be overexpressed in malignant tumors and play critical roles in mediating tumor progression. miRNAs can also function as tumor suppressors in the reciprocal by suppressing oncogene expression in cancer cells, but their expression levels are generally downregulated in tumors (14). Recently, miRNAs are suggested for their use in new therapeutic approaches, such as exogenous introduction of tumor suppressive miRNAs in the clinic. Recently, the miR-29a/b/c family was shown to have inhibitory roles in lung cancer progression (15-17). A previous study revealed that miR-29 promoted stem cell differentiation by targeting YY1 in smooth muscle cells, and showed the potential regulation of YY1 by miR-29a in cancer stem cells (16). Other studies have demonstrated that under regulation of $\mathrm{NF}-\kappa \mathrm{B}, \mathrm{YY} 1$ was inhibited by miR-29a 
in smooth muscle cells (15). Since YY1 plays an important role in mediating IL-13-induced lung cancer progression, how miR-29a is involved in IL-13-induced lung cancer cell invasion, and how miR-29a executes its role as tumor suppression remain unclear.

In the present study, we aimed to investigate the role of miR-29a in cell invasion mediated by IL-13 in lung cancer. We investigated how miR-29a is involved in the IL-13/PI3K/AKT/YY1 pathway in lung tumorigenesis, and we showed whether miR-29a can act as the potential therapeutic target in lung cancer.

\section{Materials and methods}

Cell culture and drug treatment. Human lung adenocarcinoma cell line A549 was purchased from Shanghai Cell Bank, Chinese Academy of Sciences (Shanghai, China). A549 cells were cultured in Dulbecco's modified Eagle's medium (DMEM; Gibco; Thermo Fisher Scientific, Inc., Waltham, MA, USA), which contained $10 \%$ fetal bovine serum (FBS), $100 \mu \mathrm{g} / \mathrm{ml}$ penicillin and $50 \mu \mathrm{g} / \mathrm{ml}$ streptomycin at $37^{\circ} \mathrm{C}$ in an incubator with $5 \% \mathrm{CO}_{2}$. A549 cells were serum-starved for $24 \mathrm{~h}$, and were then treated with IL-13 (Sigma-Aldrich; Merck KGaA, Darmstadt, Germany) at different concentrations or for specified hours to investigate its functions. In addition, pretreatment with $40 \mu \mathrm{M}$ PI3K/AKT pathway inhibitor LY294002 (Sigma-Aldrich; Merck KGaA) was also implemented in our studies.

Real-time quantitative PCR.The total RNA was extracted using TRIzol reagent (Sigma-Aldrich; Merck KGaA). Spectrometer and agarose electrophoresis were used to measure the RNA concentration and detect whether or not RNA was degraded. The total RNA was reverse-transcribed to cDNA and the oligo(dT) was used as a primer (Reverse Transcription Kit cat. no. AH401-01; Beijing Transgen Biotech Co.,Ltd., Beijing, China). The amplification and detection were performed using Applied Biosystems 7500 Real-Time PCR Systems (Thermo Fisher Scientific, Inc.). The thermocycling conditions were set as follows: $95^{\circ} \mathrm{C}$ for $10 \mathrm{~min}$ followed by 40 cycles of $95^{\circ} \mathrm{C}$ for $15 \mathrm{sec}$ and $60^{\circ} \mathrm{C}$ for $1 \mathrm{~min}$. The primers for GAPDH and YY1 gene were designed by Primer Premier 5.0 software (Premier Biosoft International, Palo Alto, CA, USA) and were synthesized by Takara Bio (Shiga, Japan) (Table I). The relative expression quantities of the target genes were evaluated using the $2^{-\Delta \Delta \mathrm{Ct}}$ method and mRNA and miRNA were normalized to the expression quantity of GAPDH and U6 snRNA, respectively.

Western blot analysis. The expression levels of YY1, AKT, pAKT and $\mathrm{N}$-cadherin were examined by western blot assay. Cellular proteins were extracted using RIPA protein lysate (Applygen Technologies Inc., Beijing, China). The protein concentration was detected by the BCA assay (Beyotime Institute of Biotechnology, Shanghai, China). An equal amount of proteins for each group was loaded, separated by sodium dodecyl sulfate-polyacrylamide gel electrophoresis (SDS-PAGE, 15\%), and then transferred onto polyvinylidene fluoride membranes (Beyotime Institute of Biotechnology), and blocked with 5\% skim milk. Membranes were incubated
Table I. Primer sequences.

\begin{tabular}{|c|c|c|}
\hline Gene & Primer & Sequence $\left(5^{\prime}-3^{\prime}\right)$ \\
\hline \multirow[t]{2}{*}{ GAPDH } & Forward & $\begin{array}{l}\text { CGGAGTCAACGGATTTGGTC } \\
\text { GTAT }\end{array}$ \\
\hline & Reverse & $\begin{array}{l}\text { AGCCTTCTCCATGGTGGTGAA } \\
\text { GAC }\end{array}$ \\
\hline \multirow[t]{2}{*}{ YY1 } & Forward & GAAGCCCTTTCAGTGCACGTT \\
\hline & Reverse & ACATAGGGCCTGTCTCCGGTAT \\
\hline \multirow[t]{2}{*}{$\operatorname{miR}-29 a$} & Forward & $\begin{array}{l}\text { CGCGGATCCATGGTTAAAGAG } \\
\text { CCCAATGTATGCTG }\end{array}$ \\
\hline & Reverse & $\begin{array}{l}\text { CCCAAGCTTTCAGTATAACCA } \\
\text { TTCATGATATGCTAA }\end{array}$ \\
\hline \multirow[t]{2}{*}{ U6 } & Forward & CTCGCTTCGGCAGCACA \\
\hline & Reverse & AACGCTTCACGAATTTGCGT \\
\hline
\end{tabular}

Table II. Sequences of miR-29a.

\begin{tabular}{lc}
\hline Plasmid & \multicolumn{1}{c}{ Sequence (5'-3') } \\
\hline NC & AAATGTACTGCGCGTGGAGAC \\
Mimic & TAGCACCATCTGAAATCGGTTA \\
Inhibitor & TAACCGATTTCAGATGGTGCTA
\end{tabular}

miRNA, microRNA; NC, non-coding sequence.

with primary antibodies: YY1 (cat. no. ab10923; Abcam, Cambridge, MA, USA), AKT (cat. no. C67E7; Cell Signaling Technology, Danvers, MA, USA), pAKT Ser473 (cat. no. 9271; Cell Signaling Technology) and N-cadherin (cat. no. D4R1H; Cell Signaling Technology) (diluted by 1:2,000) and $\beta$-actin antibody (cat. no. ZB2305; ZEGB-Bio Ltd., Beijing, China), respectively, at $4^{\circ} \mathrm{C}$ overnight. Membranes were washed with TBST 3 times (10 min each) and incubated with secondary antibodies (diluted by 1:5,000), HRP-labeled goat anti-mouse IgG $(\mathrm{H}+\mathrm{L})$ and HRP-labeled goat anti-rabbit $\operatorname{IgG}(\mathrm{H}+\mathrm{L})$, (cat. no. ZB2301; ZSGB-BIO) at room temperature for $2 \mathrm{~h}$. After that, the membranes were washed again with TBST another 3 times (10 min each). The Western blot substrate kit (Biovision, Inc., Milpitas, CA, USA) was used to detect protein bands. The band intensities in the western blots were determined by ImageJ software (version 1.51; NIH, Bethesda, MD, USA).

Cell transfection and construction of stable cell line. A549 cells were transfected with the miR-29a plasmid, miR-29a inhibitor and miRNA NC sequences (Table II) that were all purchased from Shanghai GenePharma Technology Ltd., Co. Transfection was carried out using Invitrogen Lipofectamine 2000 (Thermo Fisher Scientific, Inc.) and cells were cultured at $37^{\circ} \mathrm{C}$ in an incubator with $5 \% \mathrm{CO}_{2}$. Transfection efficiency was observed under a fluorescence microscope after 4-8 $\mathrm{h}$ and the complete medium was replaced. Then cell culture was continued for 24-48 h. To establish a stable transfected RNAi A549 cell line, the cells were transferred to a $10-\mathrm{cm}$ Petri dish to grow. 
A

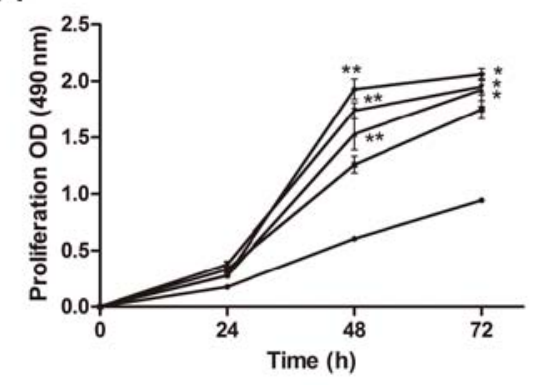

C

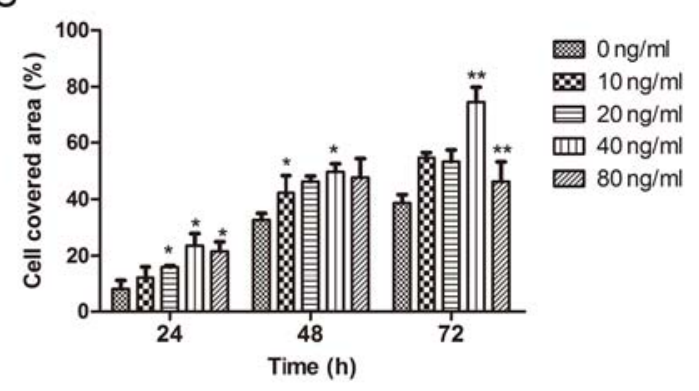

B

B $\begin{gathered}\mathrm{IL}-1 / 3 \\ 0 \mathrm{ng} / \mathrm{m} /\end{gathered}$

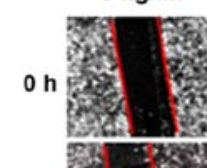

$24 \mathrm{~h}$

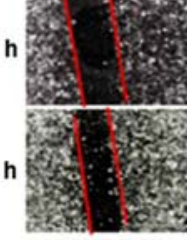

$72 \mathrm{~h}$

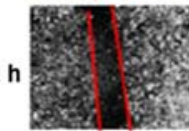

$-0 \mathrm{ng} / \mathrm{ml}$

$-10 \mathrm{ng} / \mathrm{m}$

$-20 \mathrm{ng} / \mathrm{m}$

$-40 \mathrm{ng} / \mathrm{ml}$

$-80 \mathrm{ng} / \mathrm{ml}$

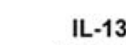

$10 \mathrm{ng} / \mathrm{ml}$

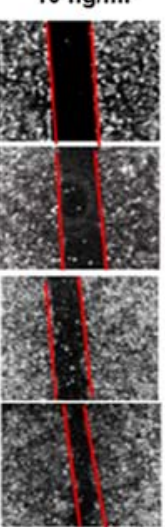

IL-13

$20 \mathrm{ng} / \mathrm{ml}$

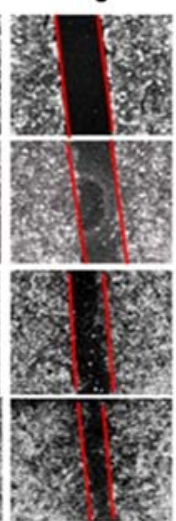

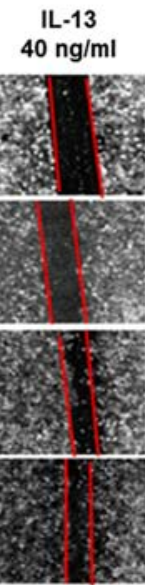

IL-13

$80 \mathrm{ng} / \mathrm{ml}$

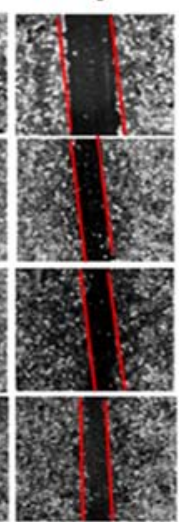

Figure 1. Effect of IL-13 on the proliferation and migration of A549 cells. (A) MTT assay. IL-13 stimulation increased the proliferation of A549 cells in a concentration- and time-dependent manner. (B) Wound-scratch test for A549 cells treated with IL-13. IL-13 with different concentrations was used to stimulate A549 cells and cell migration results were observed under an inverted microscope after 24-72 h. The image was analyzed by Image-Pro Plus. (C) Cell covered area measured from the wound-scratch test. Statistical analysis showed that IL-13 promoted the migration of A549 cells. ${ }^{*} \mathrm{P}<0.05$, $^{* *} \mathrm{P}<0.01$, compared with the $0 \mathrm{ng} / \mathrm{ml}$ group.

Blasticidin was added to select transfected cells. Then the medium was replaced every 3-4 days and the appropriate Blasticidin S was added until the formation of a resistant monoclonal colony, which took approximately 14 days. In each group, at least $10 \mathrm{drug}$-resistant clones were selected for amplification.

MTT assay. Cell proliferation was evaluated by 3-(4,5-dimethylthiazol-2-yl)-2,5-diphenyl-tetrazolium bromide (MTT) (Sigma-Aldrich; Merck KGaA) assays. The cells need to be measured were inoculated into 96 -well plates with $\sim 5 \times 10^{3}$ cells/well and each group had 5 replicates. MTT $(20 \mu 1$, $5 \mathrm{mg} / \mathrm{ml}$ ) (Sigma-Aldrich; Merck KGaA) was placed into each well and the culture process was sustained for $4 \mathrm{~h}$ at $37^{\circ} \mathrm{C}$ in an incubator with $5 \% \mathrm{CO}_{2}$. Subsequently, dimethyl sulfoxide (DMSO; $100 \mu \mathrm{l}$ ) was added into each well and the cells were gently shaken for $\sim 10 \mathrm{~min}$ to dissolve the crystals. Samples were detected using a microplate reader (Thermo Fisher Scientific, Inc.) at a wavelength of $490 \mathrm{~nm}$.

Wound-healing assay. The scratch wound-healing assay was used to assess A549 cell migration. Firstly, three uniform transverse lines were painted at the back of 6 -well plates by a marker; and then $5 \times 10^{5}$ cells were seeded into plates and cultured overnight. When the cells achieved adherence, they were starved with medium free of serum for $12 \mathrm{~h}$. Then, the medium was removed, and sterile tips $(200 \mu \mathrm{l})$ were used to draw a line which was vertical to the back-transverse lines, followed by washing the cells twice with phosphate-buffered saline (PBS). Migration distances of cells were imaged and monitored using an inverted microscope (Carl Zeiss AG, Oberkochen, Germany) with 3 randomly selected fields in the wounded region at $0,24,48$ and $72 \mathrm{~h}$. The percentage of wound width was calculated as: Wound width at $0,24,48$ or $72 \mathrm{~h}$ divided by the original wound width measured at $0 \mathrm{~h}$.

Transwell invasion assay. Transwell invasion assay was performed using 24-well Transwell plates with $8-\mu \mathrm{m}$ pores and a coating of Matrigel (100 $\mu \mathrm{l} /$ well) (BD Biosciences, San Jose, CA, USA) to measure the invasion status of A549 cells. In addition, $2 \times 10^{4}$ cells were placed in the upper Transwell chamber. Then, $600 \mu 1$ complete DMEM was added in the lower chamber as the chemo-attractant. After cells were incubated for $24 \mathrm{~h}$ at $37^{\circ} \mathrm{C}$, non-invasive cells in the top chamber were removed with cotton swabs. Invasive cells at the bottom of the membrane were fixed with methanol and then were stained with crystal violet. The number of invasive cells was counted by hemocytometry to assess the invasion status of the cells.

Flow cytometry. A549 cells were plated into 6-well tissue culture plates at $\sim 2 \times 10^{4} /$ well, each group has three duplicates. After incubation, they were harvested in $1.5 \mathrm{ml}$ EP tubes and washed with PBS. Binding buffer (500 $\mu \mathrm{l})$ was used to 

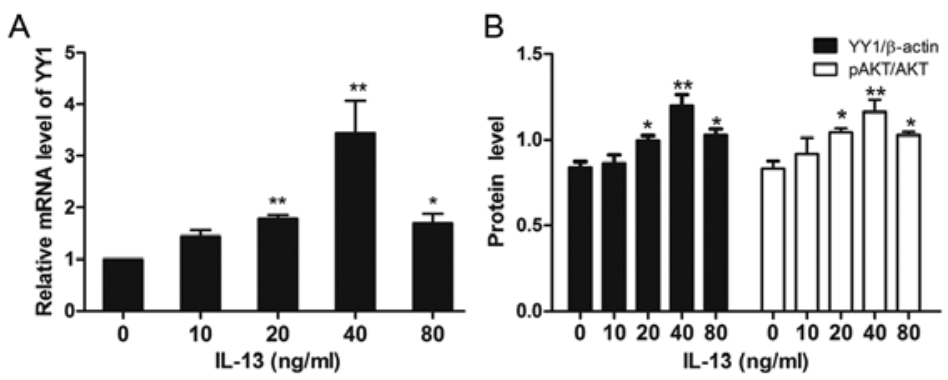

C
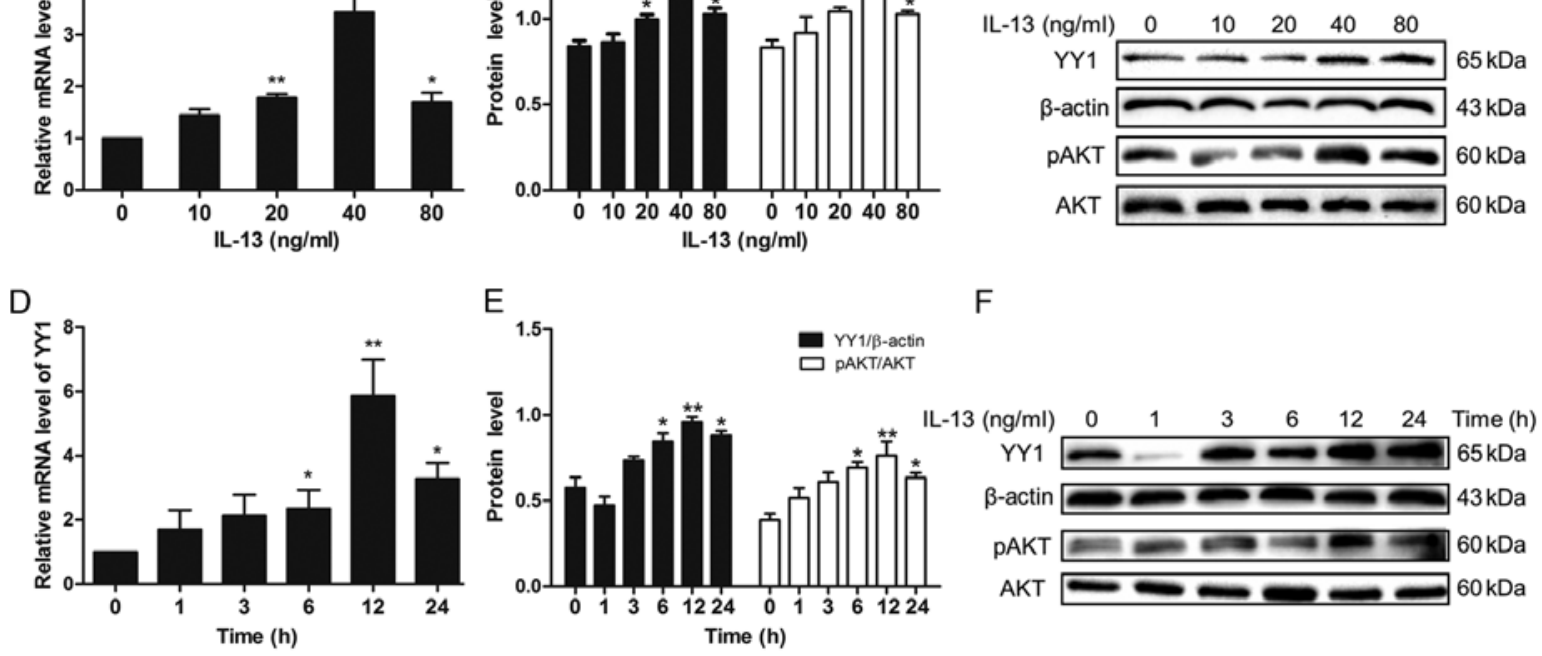

$\mathrm{F}$

G

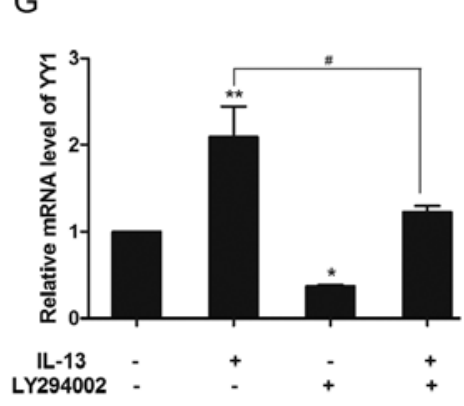

$\mathrm{H}$

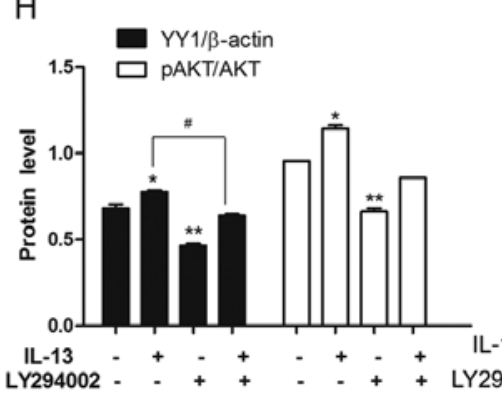

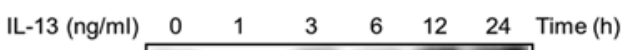

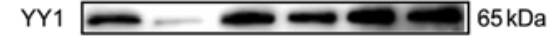

$\mathrm{B}$-actin $43 \mathrm{kDa}$
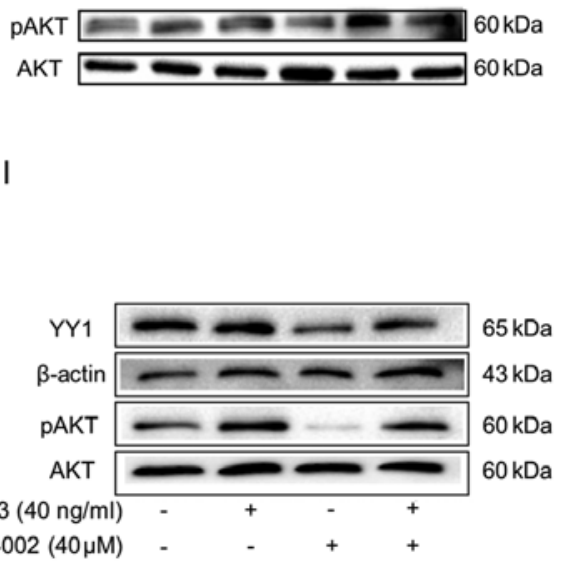

Figure 2. Effect of IL-13 on the PI3K/AKT/YY1 pathway in A549 cells. (A) qPCR was applied to detect YY1 at the mRNA level. The mRNA level of YY1 was promoted after IL-13 stimulation; and the effect was highest at $40 \mathrm{ng} / \mathrm{ml}$ IL-13. (B and C) Western blot analysis was applied to detect YY1 and pAKT protein levels. As analyzed by ImageJ software, the protein levels of YY1 and pAKT were promoted after IL-13 stimulation; these effects were highest at $40 \mathrm{ng} / \mathrm{ml}$ IL-13 ( $\mathrm{P}<0.05,{ }^{* *} \mathrm{P}<0.01$, compared with the $0 \mathrm{ng} / \mathrm{ml}$ group). (D) The mRNA level of YY1 was promoted after the stimulation of $40 \mathrm{ng} / \mathrm{ml} \mathrm{IL}-13 \mathrm{for} 24 \mathrm{~h}$ while at $12 \mathrm{~h}$ this effect was the highest. (E and F) As analyzed by ImageJ software, the protein levels of YY1 and pAKT were promoted after IL-13 stimulation while the effect at $12 \mathrm{~h}$ was the highest $\left(" \mathrm{P}<0.05,{ }^{* *} \mathrm{P}<0.01\right.$, compared with the $0 \mathrm{~h}$ group). (G) Addition of LY294002 inhibited YY1 expression at the mRNA level. (H and I) As analyzed by ImageJ software, the protein levels of YY1 and pAKT were inhibited by LY294002 ["P $<0.05$, ${ }^{* *} \mathrm{P}<0.01$, blank group; ${ }^{"} \mathrm{P}<0.05$, IL-13 group by IL-13(+) LY294002(-)/IL-13(-) LY294002(-) and IL-13(+) LY294002(+)/IL-13(-) LY294002(+)]. In G and H and Fig. 3C, background signals in the YY1 expression and cell migration are at an unequal level when compared treatment with LY294002 (-) and (+).

resuspend the cells. Then Annexin-FITC and propidium iodide (PI), each $5 \mu 1$, were added in EP tubes, being fully mixed; followed by incubation for $15 \mathrm{~min}$ at room temperature in the dark. Data acquisition was performed with FACSCalibur flow cytometry (Becton Dickinson, San Jose, CA, USA).

Statistical analysis. Data presented as bar graphs are the means $\pm \mathrm{SD} / \mathrm{SED}$ of at least three independent experiments. The statistical significance of data was analyzed by one-way ANOVA through SPSS 20.0 software (IBM Corp., Armonk, NY, USA). Two-sided $\mathrm{P}<0.05$ was defined as the cut-off value for evaluating statistical significance.

\section{Results}

IL-13 promotes the proliferation and migration of A549 cells. A549 cells were stimulated with different concentrations of IL-13 $(0,10,20,40$ and $80 \mathrm{ng} / \mathrm{ml})$ for 24-72 h. Compared to the control group $(0 \mathrm{ng} / \mathrm{ml})$, proliferation of A549 cells was accelerated after being treated with IL-13, and the concentration of IL-13 at $40 \mathrm{ng} / \mathrm{ml}$ showed the most significant induction $(\mathrm{P}<0.01,48 \mathrm{~h} ; \mathrm{P}<0.05,72 \mathrm{~h})$ (Fig. 1A). We found that IL-13 promoted the migration of A549 cells, and the optimal concentration of IL-13 at $40 \mathrm{ng} / \mathrm{ml}$ was used and it exhibited the strongest ability to induce cell migration, while the concentration of IL-13 at $80 \mathrm{ng} / \mathrm{m}$ only showed a slight increase in cell migration (Fig. 1B and C). These results indicated that IL-13 promoted proliferation and migration of A549 cells in a concentration- and time-dependent manner.

IL-13 activates the PI3K/AKT/YY1 pathway in A549 cells. To investigate the mechanism underlying the induction of cell proliferation and migration by IL-13 in A549 cells, we examined the regulation of the PI3K/AKT pathway and the transcription factor YY1 by IL-13. The PI3K inhibitor LY294002 was used to block the PI3K/AKT pathway and to examine the YY1 expression level in this pathway. Our data determined that IL-13 stimulation of all concentrations (with $40 \mathrm{ng} / \mathrm{ml}$ the strongest) promoted YY1 expression at the mRNA level compared with the control group $(\mathrm{P}<0.01)$ (Fig. 2A). We further examined the 
A

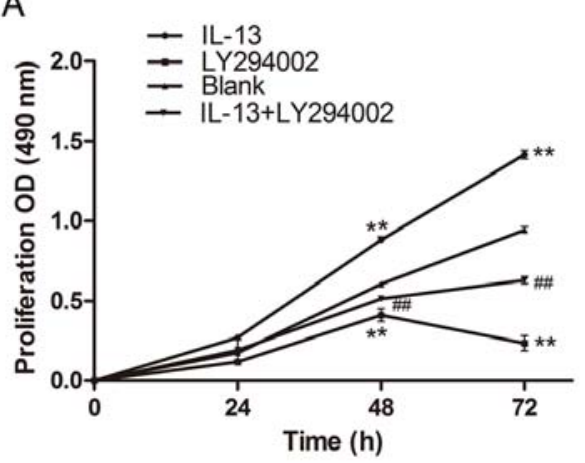

C

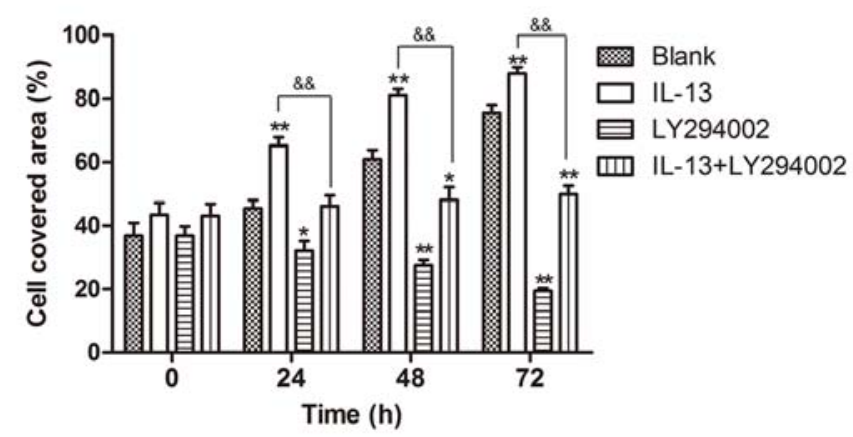

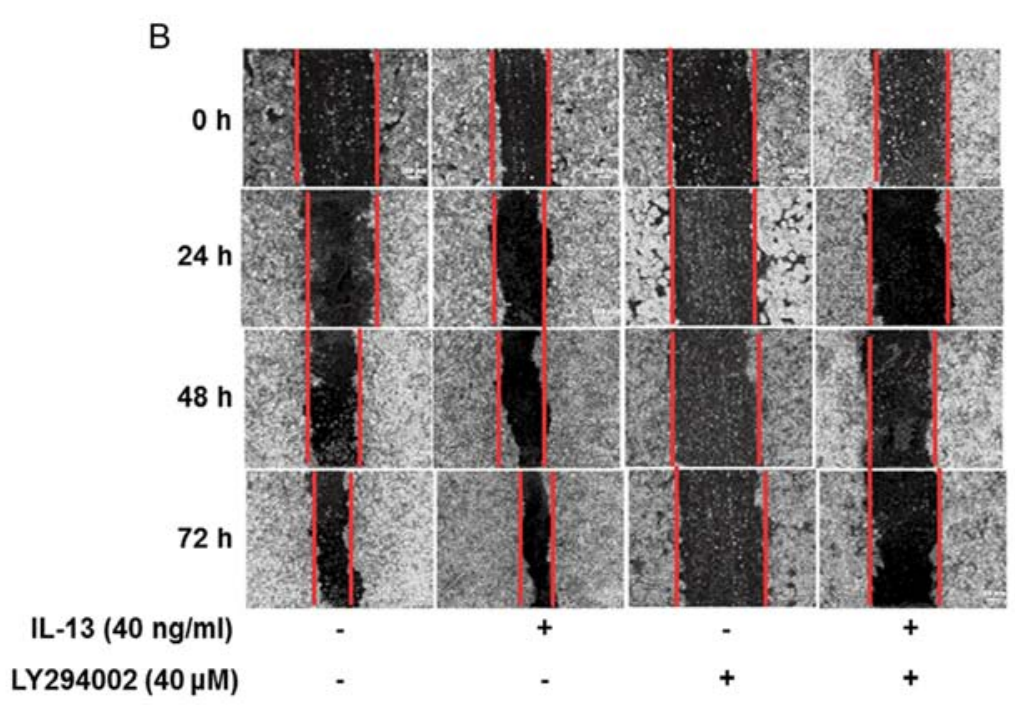

Figure 3. Effect of the PI3K/AKT pathway on IL-13-induced proliferation and migration of A549 cells. (A) IL-13 promoted the proliferation of A549 cells by MTT assay in a PI3K/AKT-dependent manner. Following treatment of A549 cells with either IL-13 or with IL-13+LY294002, cell proliferation was assessed. Inhibition of PI3K/AKT blocked the cell growth of A549 cells. (B) IL-13 promotes the migration of A549 cells as detected by wound-scratch assay. Migration ability of the A549 cells treated with either IL-13 or with IL-13+LY294002 was determine by gap closure in a culture plate. Cells were incubated for $24 \mathrm{~h}$ and the gap between the scratch was imaged by microscopy. (C) Quantification of the cell migration in the A549 cells treated with either IL-13 or IL-13+LY294002. The image of the gap was captured and gap distance was calculated by ImageJ software. IL-13 promoted the migration of A549 cells while inhibition of the PI3K/AKT pathway by LY294002 blocked cell migration. ${ }^{*} \mathrm{P}<0.05,{ }^{* *} \mathrm{P}<0.01$, compared with the blank group; ${ }^{\star} \& \mathrm{P}<0.01$, ${ }^{\# \#} \mathrm{P}<0.01$, compared with the IL-13 group.

protein expression level of YY1 by western blot analysis, and it showed that YY1 and pAKT protein levels were increased after IL-13 stimulation compared with the control group. Consistently, the protein expression levels of YY1 and pAKT indicated highest induction following treatment with IL-13 at $40 \mathrm{ng} / \mathrm{ml}$ in the A549 cells $(\mathrm{P}<0.05)$ (Fig. 2B and C). The mRNA level of YY1 showed highest induction after being treated with $40 \mathrm{ng} / \mathrm{ml} \mathrm{IL}-13$ stimulation for $12 \mathrm{~h}$ (Fig. 2D and E). This showed that IL-13 can upregulate YY1 expression level in A549 cells and this induction was correlated with the concentration of IL-13 and time period. The increased level of AKT phosphorylation in A549 cells treated with IL-13 demonstrated activation of the PI3K/AKT pathway triggered by IL-13 (Fig. 2E and F). To determine whether YY1 expression level was regulated by the PI3K/AKT pathway, we used $40 \mu \mathrm{M} \mathrm{LY} 294002$ in addition to IL-13 (40 ng/ml) to stimulate the A549 cells in the experimental group. Following inhibition of the PI3K/AKT pathway, we did not observe the induction of YY1 at both the mRNA and protein level after IL-13 treatment in the lung cancer cells. This indicated that upregulation of YY1 by IL-13 was mediated by activation of the PI3K/AKT pathway (Fig. 2G-I).
IL-13 promotes the proliferation and migration of A549 cells through the PI3K/AKT/YY1 pathway. To determine whether IL-13-induces cell proliferation and migration in lung cancer depends on activation of the PI3K/AKT signaling pathway, we co-treated A549 cells with LY294002 $(40 \mu \mathrm{M})$ and IL-13 (40 ng/ml) for 24-72 h. Our results showed that treatment with IL-13 induced cell proliferation, but blocking the PI3K/AKT pathway by LY294002 inhibited cell growth in the A549 cells $(\mathrm{P}<0.01)$ (Fig. 3A). IL-13 stimulation activated PI3K/AKT signaling in the A549 cells and significantly promoted cell migration as determined by a wound-healing assay (Fig. 3B and C). We further assessed the cell migration effects induced by IL-13 by blocking the PI3K/AKT pathway using LY294002. We observed a reduced cell covered area in the LY294002 group, which suggested that inhibition of the $\mathrm{PI} 3 \mathrm{~K} / \mathrm{AKT}$ pathway weakened the migratory ability in original A549 cells comparing to the control group. Deactivating the PI3K/AKT pathway impaired cell migration induced by IL-13 in the A549 cells $(\mathrm{P}<0.01)$ (Fig. 3B and $\mathrm{C}$ ), which indicated that IL-13 induced cell proliferation and migration mainly by activating the PI3K/AKT signaling pathway. 
A

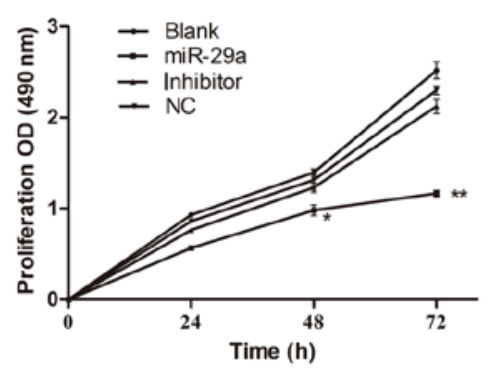

C

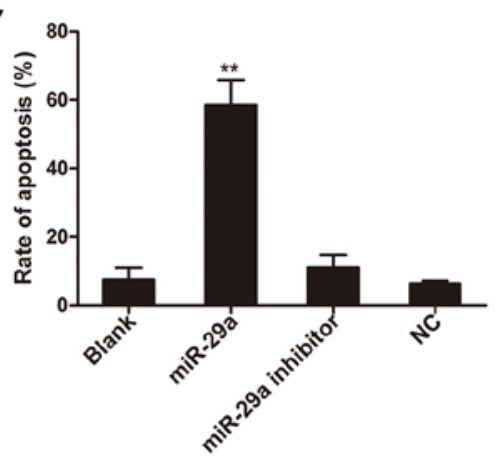

B
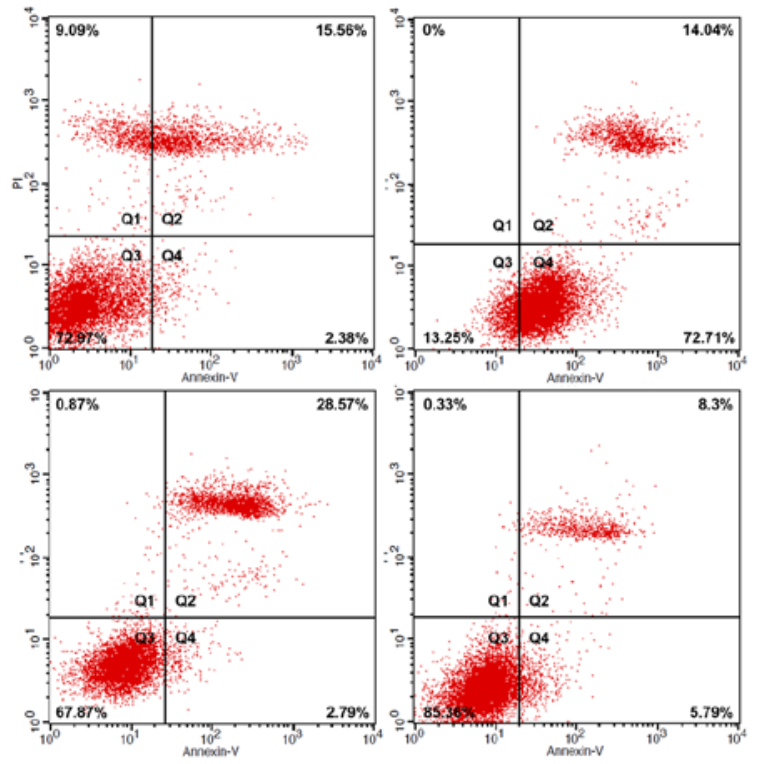

D
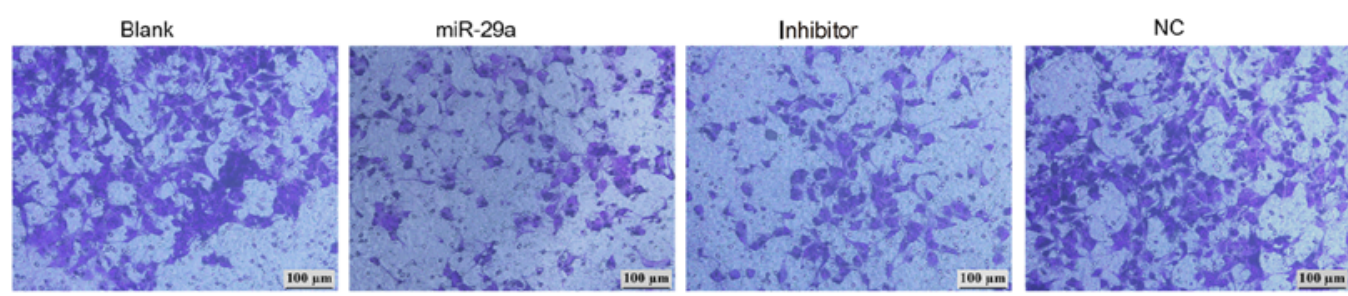

E

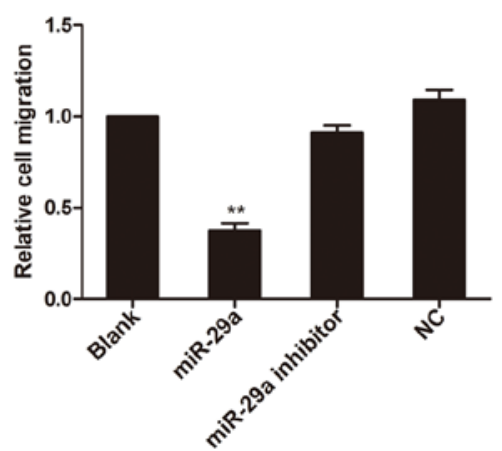

Figure 4. Regulation of biological behavior of the A549 cells by miR-29a. (A) MTT assay. miR-29a inhibited the proliferation of A549 cells in the miR-29a group, while in the other groups such an effect was not seen. (B and C) Flow cytometric Annexin V-PI assay. The apoptosis of A549 cells was enhanced following treated with miR-29a. (D and E) Transwell invasion assay. The cell invasion ability was inhibited following treated with miR-29a while its inhibitor did not induce a specific significance in the process $\left({ }^{*} \mathrm{P}<0.05,{ }^{* *} \mathrm{P}<0.01\right.$, compared with the blank group). (A and D) There were no significant differences between the miR-29 inhibitor-transfected and NC group.

miR-29a inhibits proliferation and migration of A549 cells. Previous reports have shown that miR-29a is involved in cell growth in other types of cancer. To test whether miR-29a exhibits an inhibitory function in lung cancer induced by IL-13, we overexpressed miR-29a expression in vitro by transfecting A549 cells with the miR-29a sequence. By MTT assay, we showed that cell proliferation in the A549-miR-29a group was inhibited with the most extensive inhibitory effects at 48 and $72 \mathrm{~h}(\mathrm{P}<0.05$ and $\mathrm{P}<0.01$ respectively) (Fig. 4A). Overexpression of miR-29a promoted cell apoptosis and inhibited cell invasion in the A549 cells (Fig. 4B-E). To examine the molecular mechanism of miR-29a in lung cancer induced by IL-13, we measured the expression level of YY1 in the miR-29a-overexpressing A549 cells. Our results showed that a decline in YY1 expression was observed at both mRNA and protein level under miR-29a treatment (Fig. 5A-C). In contrast, transfection with the miR-29a inhibitor upregulated the expression level of YY1 (Fig. 5A-C). We found that YY1 expression was negatively correlated with miR-29a. Furthermore, we measured the expression levels of $\mathrm{N}$-cadherin (a biomarker for invasive cells), and our results showed that $\mathrm{N}$-cadherin was 


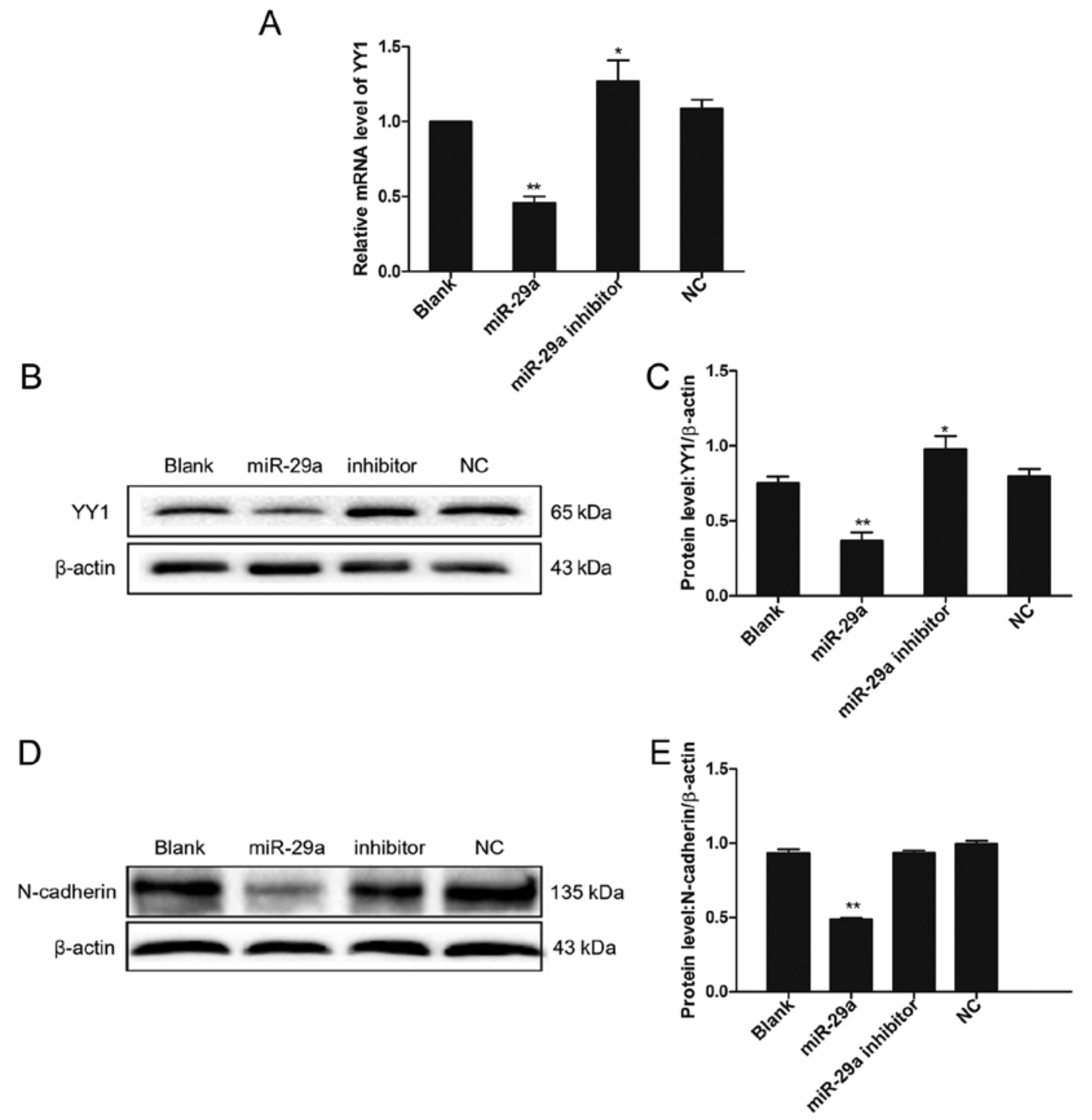

Figure 5. Regulation of YY1 and N-cadherin by miR-29a. (A) miR-29a inhibits the mRNA level of YY1 in A549 cells. miR-29a was overexpressed and miR-29a was knocked down by transfection of the A549 cells before measuring the mRNA level by RT-qPCR assay. (B) miR-29a reduced the protein level of YY1 in A549 cells. The protein level of YY1 was measured by western blot analysis. (C) Quantification of the protein expression level of YY1 as analyzed by ImageJ software. (D) miR-29a reduced the protein level of $\mathrm{N}$-cadherin in the A549 cells. The protein level of $\mathrm{N}$-cadherin was measured by western blot analysis. (E) Quantification of the protein expression level of $\mathrm{N}$-cadherin as analyzed by ImageJ software. ${ }^{*} \mathrm{P}<0.05$, ${ }^{* *} \mathrm{P}<0.01$, compared with the blank group.

significantly downregulated in the miR-29a-overexpression group, compared to the control (Fig. 5D and E), which validated the inhibitory role of miR-29a in cell invasion in lung cancer.

miR-29a inhibits IL-13-induced cell invasion by targeting YY1. Since YY1 expression level was correlated with IL-13 and miR-29a, we determine whether miR-29a affects the role of IL-13 in lung cancer A549 cells. Overexpression of miR-29a in the IL-13-treated group significantly downregulated cell proliferation and invasion in A549 cells, as compared to the control group treated with IL-13 (Fig. 6A-C). We measured the related YY1 expression levels in the groups, and we found that overexpression of miR-29a significantly reduced YY1 expression $(\mathrm{P}<0.01)$ (Fig. 6D-F). This showed that under stimulation of IL-13, miR-29a overexpression repressed YY1 expression and inhibited the malignant behaviors of A549 cells mediated by IL-13.

\section{Discussion}

The phosphoinositide 3-kinase/serine-threonine kinase (PI3K/AKT) signaling pathway plays a pivotal role in tumorigenesis due to its regulation of cellular functions, including proliferation, differentiation and metastasis of cancer cells $(18,19)$. Excessive activation of the PI3K/AKT pathway in normal cells could trigger their transformation into cancer cells, and the expression levels of PI3K and AKT are increased in NSCLC (20). Previous studies have shown that IL-13 activates the PI3K/AKT signaling pathway in porcine endothelial cells and human dermal fibroblasts $(10,11)$, but how IL-13 regulates lung cancer cells remains largely unknown. Our results showed that within a certain range, rising concentrations of IL-13 (from 0 to $40 \mathrm{ng} / \mathrm{ml}$ ) and increasing periods of timeC (from 0 to $12 \mathrm{~h}$ ) were associated with the gradually increased amount of pAKT in A549 cells, indicating that IL-13 is one of the simulative factors of the PI3K/AKT pathway in human lung 


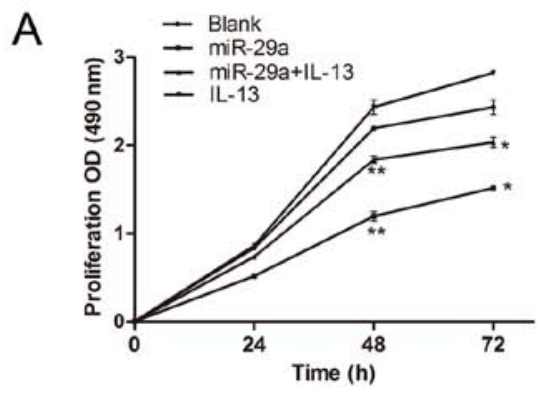

B

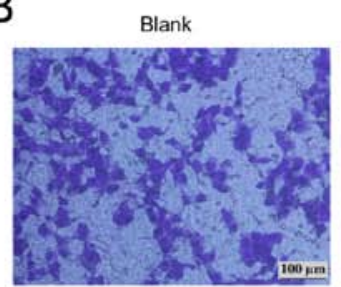

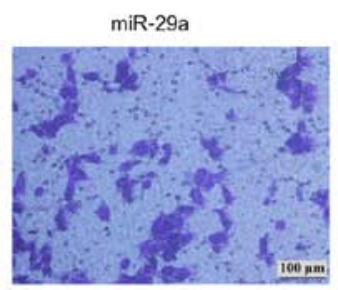
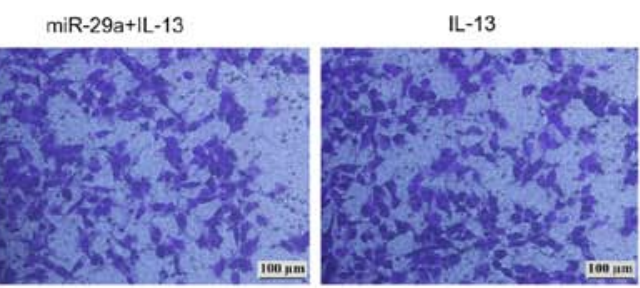

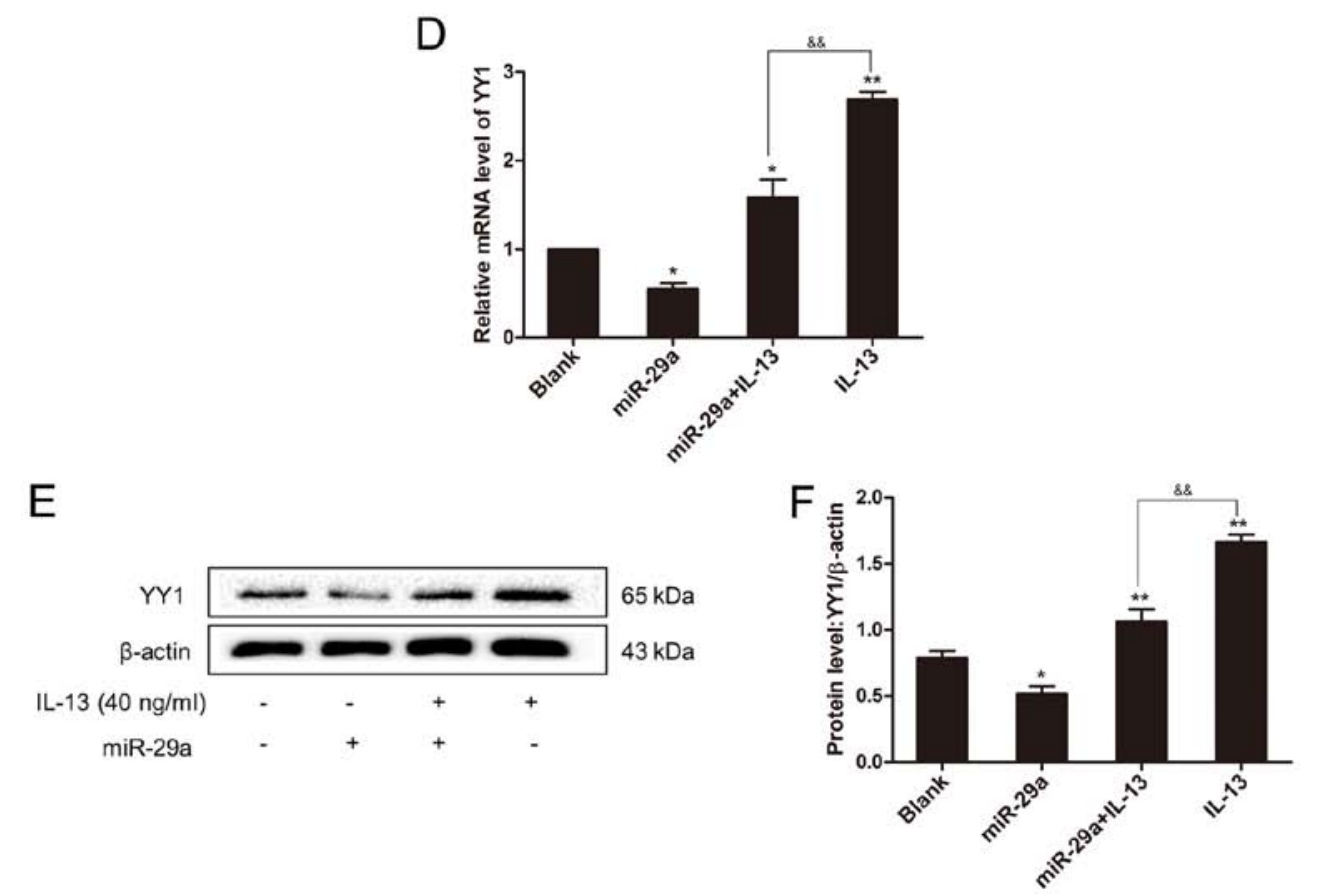

Figure 6. Effect of miR-29a on YY1 expression and cell behavior following IL-13 treatment. (A) MTT assay. miR-29a inhibited the cell proliferation promoted by IL-13. (B) miR-29a inhibits cell invasion in A549 cells by Transwell chamber assay. Overexpression of miR-29a or knockdown of miR-29a was carried out by transfection of A549 cells and cells were then treated with IL-13. Cell invasion ability was measured by Transwell assay. (C) Quantification of the number of invasive cells from B. (D) Measurement of the YY1 mRNA level in A549 cells treated with miR-29a overexpression vector or IL-13 stimulation. The mRNA level of YY1 was measured by RT-qPCR and normalized by GAPDH. (E) Determination of the YY1 protein level in A549 cells treated with miR-29a overexpression vector or IL-13 stimulation. The protein level of YY1 was determined by western blot analysis. (F) Quantification of the protein expression level of YY1 from $\mathrm{E}$ as analyzed by ImageJ software ${ }^{*} \mathrm{P}<0.05,{ }^{* *} \mathrm{P}<0.01$, compared with the blank group; ${ }^{\& \&} \mathrm{P}<0.01$, compared with IL-13 group.

cancer. Furthermore, we demonstrated that IL-13 increased cell proliferation and migration abilities in lung cancer cells by activating the PI3K/AKT pathway. Our findings are consistent with a previous study which showed that IL-13R $\alpha 2$ is able to activate the Scr/PI3K/AKT/mTOR pathway (21).

YY1 is one of the direct downstream effectors of AKT (22-24). Silencing of AKT can decrease the YY1 protein level to approximately 50\% (12). Consistently, we showed that treatment of A549 cells with LY294002 decreased the pAKT level subsequently decreasing the YY1 level at both the mRNA and protein levels. The identification of the
IL-13/PI3K/AKT/YY1 signaling transduction pattern was reported previously in lung fibroblasts (13), but it has not been confirmed in lung cancer cells. By using lung cancer cell line A549, we showed that IL-13 stimulation was positively correlated with the levels of pAKT and YY1 in a time- and concentration-dependent manner, indicating the importance of the IL-13/PI3K/AKT/YY1 pathway in lung tumorigenesis. Compared with the blank group, proliferation of A549 cells decreased obviously when treated with LY294002. AKT controls cell proliferation by directly phosphorylating the glycogen synthase kinase-3 $\beta$ (GSK3 $\beta$ ) (25) and 
negatively influences expression of CKIs to accumulate CDK complexes (26). We further showed that the increased migration of A549 cells treated with IL-13 and promotion of the processes of epithelial-mesenchymal transition (EMT) and inhibition the PI3K/AKT pathway by LY294002 could attenuate the EMT process. Recently, EMT has been reported to play a key role in the migration of cancer cells. Others have reported that AKT forms a positive loop with TWIST in EMT-induced events, and AKT inhibition causes downregulation of Snail and upregulation of E-cadherin (27).

Recently, miRNAs have been shown to play important roles in every step of cancer progression. In our results, transfection with miR-29a inhibited the proliferation of A549 cells and enhanced their apoptosis by mediating expression of YY1 in cell cycle regulation. Activation of cyclin D1 was found to coincide with the release of YY1 transcriptional repressor complex in estrogen-responsive human breast cancer (28). Previous groups have shown that YY1 is inhibited by $p 53$ (29). YY1 activates both endogenous and exogenous $c-M y c$ promoter when overexpressed, thus inhibiting the function of $p 21(30,31)$. YY1 was found to activate transcription of the NF- $\kappa \mathrm{B}$ subunits, Rel-A and Rel-B, and also compete with $\mathrm{NF}-\kappa \mathrm{B}$ for binding the cytokine response unit within the serum amyloid A gene promoter (32-34). YY1 has been shown to repress expression of Fas and DR5, increasing resistance to apoptosis $(35,36)$. In the present study, we demonstrated that invasion of lung cancer was positively related with YY1 expression. Previous reports have demonstrated that YY1 binds to the matrix metalloproteinases-2 (MMP-2) promoter to promote its expression, causing the remodeling of the extracellular matrix (ECM) $(37,38)$. We showed that the reduction in N-cadherin after transfecting miR-29a implied that EMT may participate in the YY1-regulated tumor cell biological behavior. miR-29a is predicted to have a complementary site in YY1 3'UTR (position 774-780 of YY1 3'UTR: 5'-UGG UGCUC; hsa-miR-29a-3p: 3'-ACCACGAG). We indicated that miR-29a repressed YY1 expression at both the mRNA and protein levels, leading to inhibition of cell proliferation and invasion of A549 cells. In Fig. 4, we did not observe any significant differences between miR-29a inhibitor-transfected and NC group based on our data. It may be due to the fact that the endogenous level of miR-29a in A549 cells was very low, and it did not show any difference when we further knocked down its level. But instead, it showed significant effects when we overexpressed it in cells. miR-29a plays an inhibitory role in EMT, in particular it inhibits transition from epithelial to mesenchymal form of cells. $\mathrm{N}$-cadherin is the chosen marker for mesenchymal cells and suppression of $\mathrm{N}$-cadherin confirms our hypothesis that miR-29a acts as a tumor suppressor miRNA to inhibit cell invasion. While E-cadherin is a marker for epithelial cells, a further study of EMT may utilize both $\mathrm{N}$-cadherin and E-cadherin expression levels to monitor the process of EMT.

Previously, miR-29a has been shown to inhibit tumorigenicity in NSCLC by downregulating DNA methyltransferase (DNMT)3A and 3B, which silence tumor suppressor genes such as FHIT and WWOX (39). Overexpression of miR-29a was found to reduce the proliferation, migration, and invasion of NSCLC cells, which could be partially attributed to LASP-1 (a cAMP and cGMP dependent signaling protein) inhibition (40). In the present study, we further examined the role of miR-29a in IL-13-induced lung cancer progression, and we showed that miR-29a inhibited lung cancer progression by targeting YY1 in the PI3K/AKT pathway. We hypothesized that miR-29a plays an important role in regulating lung cancer tumorigenicity through repression of signaling protein LASP-1, transcription factor YY1, and epigenetic factors DNMT3A and 3B. In our data, we significantly showed that miR-29a transfection greatly weakened IL-13-induced lung cancer progression and led to YY1 repression, causing lower proliferation and weaker invasive ability in A549 cells. These results indicated that miR-29a could act as a promising therapeutic target for NSCLC. We may use miR-29a to antagonize the effects induced by IL-13 on tumor cell behavior and inhibit expression of YY1 in lung cancer. A previous study showed that miR-29a regulated expression of YY1, but this was shown in lung fibroblasts (16). In the present study, we further demonstrated the role of miR-29a in lung cancer cells instead of lung fibroblasts, which provides new evidence that miR-29a is involved in IL-13-induced cell invasion in lung cancer. In this study, we elucidated the role of miR-29a in the IL-13/PI3K/AKT/YY1 signaling pathway in lung cancer that represents a novel finding. We further examined the activation of the PI3K/AKT pathway in lung cancer A549 cells, and measured the phosphorylation of AKT following IL-13 stimulation. In addition, we investigated whether blocking the PI3K/AKT pathway would affect the effects of YY1 mediated by miR-29a and IL-13. However, our studies were limited to in vitro experiments, which cannot entirely represent these mechanisms at the individual level. Further research on miR-29a in a corresponding animal model may provide more evidence for clinical molecular-targeted treatment of lung cancer.

In summary, we identified the activation of the PI3K/AKT/YY1 signaling pathway in IL-13-induced lung cancer progression. By overexpression miR-29a, we blocked IL-13-induced YY1 to inhibit its tumor-promoting functions in A549 cells. Further research on miR-29a including in vitro and animal model studies may provide more evidence for clinical molecular-targeted treatment of lung cancer.

\section{Acknowledgements}

Not applicable.

\section{Funding}

The present study was supported by the National Natural Science Foundation of China (nos. 81200069 and 31660287); the National Natural Science Foundation of Jiangxi Province (no. 20161BAB205204); the Science and Technology Plan of Education Department of Jiangxi Province (no. 150217); and the Postgraduates Innovation Special Fund Project of Nanchang University (no. cx2016356).

\section{Availability of data and materials}

All data generated or analyzed during this study are included in this published article. 


\section{Authors' contributions}

YZ was in charge for thesis writing and modification. SH and RM were responsible for conducting the experiments and in charge of constructing the graphs. All authors contributed equally to this study. All authors read and approved the manuscript and agree to be accountable for all aspects of the research in ensuring that the accuracy or integrity of any part of the work are appropriately investigated and resolved.

\section{Ethics approval and consent to participate}

The study used cell lines and thus ethical approval was waived.

\section{Consent for publication}

Not applicable.

\section{Authors' information}

\section{ORCID ID: 0000-0003-3769-2496 for LX.}

\section{Competing interests}

The authors declare that they have no competing interests.

\section{References}

1. Lemjabbar-Alaoui H, Hassan OU, Yang YW and Buchanan P: Lung cancer: Biology and treatment options. Biochim Biophys Acta 1856: $189-210,2015$

2. Joshi BH, Hogaboam C, Dover P, Husain SR and Puri RK: Role of interleukin-13 in cancer, pulmonary fibrosis, and other $\mathrm{T}_{\mathrm{H}}$ 2-type diseases. Vitam Horm 74: 479-504, 2006.

3. Zhu Z, Homer RJ, Wang Z, Chen Q, Geba GP, Wang J, Zhang Y and Elias JA: Pulmonary expression of interleukin-13 causes inflammation, mucus hypersecretion, subepithelial fibrosis, physiologic abnormalities, and eotaxin production. J Clin Invest 103: 779-788, 1999.

4. Fujisawa T, Joshi B, Nakajima A and Puri RK: A novel role of interleukin-13 receptor alpha2 in pancreatic cancer invasion and metastasis. Cancer Res 69: 8678-8685, 2009.

5. Fujisawa T, Joshi BH and Puri RK: IL-13 regulates cancer invasion and metastasis through IL-13R $\alpha 2$ via ERK/AP-1 pathway in mouse model of human ovarian cancer. Int $\mathbf{J}$ Cancer 131: 344-356, 2012

6. Jakubzick C, Kunkel SL, Joshi BH, Puri RK and Hogaboam CM Interleukin-13 fusion cytotoxin arrests Schistosoma mansoni egg-induced pulmonary granuloma formation in mice. Am J Pathol 161: 1283-1297, 2002

7. Shimamura T, Fujisawa T, Husain SR, Joshi B and Puri RK: Interleukin 13 mediates signal transduction through interleukin 13 receptor alpha2 in pancreatic ductal adenocarcinoma: Role of IL-13 Pseudomonas exotoxin in pancreatic cancer therapy. Clin Cancer Res 16: 577-586, 2010.

8. Erkeland SJ, Valkhof M, Heijmans-Antonissen C, Delwel R, Valk PJ, Hermans MH and Touw IP: The gene encoding the transcriptional regulator Yin Yang 1 (YY1) is a myeloid transforming gene interfering with neutrophilic differentiation. Blood 101: 1111-1117, 2003.

9. Hsu KW, Hsieh RH, Lee YH, Chao CH, Wu KJ, Tseng MJ and Yeh TS: The activated Notch1 receptor cooperates with alpha-enolase and MBP-1 in modulating $c$-myc activity. Mol Cell Biol 28: 4829-4842, 2008.

10. Grehan JF, Levay-Young BK, Fogelson JL, François-Bongarçon V, Benson BA and Dalmasso AP: IL-4 and IL-13 induce protection of porcine endothelial cells from killing by human complement and from apoptosis through activation of a phosphatidylinositide 3-kinase/Akt pathway. J Immunol 175: 1903-1910, 2005 .
11. Moriya C, Jinnin M, Yamane K, Maruo K, Muchemwa FC, Igata T, Makino T, Fukushima S and Ihn H: Expression of matrix metalloproteinase-13 is controlled by IL-13 via PI3K/Akt3 and PKC-delta in normal human dermal fibroblasts. J Invest Dermatol 131: 655-661, 2011.

12. Petrella BL and Brinckerhoff CE: PTEN suppression of YY1 induces HIF-2 activity in von-Hippel-Lindau-null renal-cell carcinoma. Cancer Biol Ther 8: 1389-1401, 2009.

13. Guo J, Yao H, Lin X, Xu H, Dean D, Zhu Z, Liu G and Sime P: IL-13 induces YY1 through the AKT pathway in lung fibroblasts. PLoS One 10: $\mathrm{e}$ 0119039, 2015.

14. Lages E, Ipas H, Guttin A, Nesr H, Berger F and Issartel JP: MicroRNAs: Molecular features and role in cancer. Front Biosci 17: 2508-2540, 2012.

15. Larsen JE and MinnarJD: Molecular biology of lung cancer: Clinical implications. Clin Chest Med 32: 703-740, 2011.

16. Jin $M$, Wu Y, Wang Y, Yu D, Yang M, Yang F, Feng $C$ and Chen T: MicroRNA-29a promotes smooth muscle cell differentiation from stem cells by targeting YY1. Stem Cell Res 17: 277-284, 2016.

17. Wang H, Garzon R, Sun H, Ladner KJ, Singh R, Dahlman J, Cheng A, Hall BM, Qualman SJ, Chandler DS, et al: NF-kappaB-YY1-miR-29 regulatory circuitry in skeletal myogenesis and rhabdomyosarcoma. Cancer Cell 14: 369-381, 2008.

18. Ebrahimi S, Hosseini M, Shahidsales S, Maftouh M, Ferns GA, Ghayour-Mobarhan M, Hassanian SM and Avan A: Targeting the Akt/PI3K signaling pathway as a potential therapeutic strategy for the treatment of pancreatic cancer. Curr Med Chem 24: 1321-1331, 2017.

19. Bahrami A, Khazaei M, Hasanzadeh M, ShahidSales S, Joudi Mashhad M, Farazestanian M, Sadeghnia HR, Rezayi M, Maftouh M, Hassanian SM and Avan A: Therapeutic potential of targeting PI3K/AKT pathway in treatment of colorectal cancer: Rational and progress. J Cell Biochem 119: 2460-2469, 2018.

20. Heavey S, O'Byrne KJ and Gately K: Strategies for co-targeting the PI3K/AKT/mTOR pathway in NSCLC. Cancer Treat Rev 40: 445-456, 2014

21. Tu M, Wange W, Cai L, Zhu P, Gao Z and Zheng W: IL-13 receptor alpha2 stimulates human glioma cell growth and metastasis through the $\mathrm{Src} / \mathrm{PI} 3 \mathrm{~K} / \mathrm{Akt} / \mathrm{mTOR}$ signaling pathway. Tumour Biol 37: 14701-14709, 2016.

22. Berns KI and Bohenzky RA: Adeno-associated viruses: An update. Adv Virus Res 32: 243-306, 1987.

23. Shi Y, Seto E, Chang LS and Shenk T: Transcriptional repression by YY1, a human GLI-Kruppel-related protein, and relief of repression by adenovirus E1A protein. Cell 67: 377-388, 1991.

24. Park K and Atchison ML: Isolation of a candidate repressor/activator, NF-E1 (YY-1, delta), that binds to the immunoglobulin kappa 3' enhancer and the immunoglobulin heavy-chain mu E1 site. Proc Natl Acad Sci USA 88: 9804-9808, 1991.

25. Diehl JA, Cheng M, Roussel MF and Sherr CJ: Glycogen synthase kinase-3beta regulates cyclin D1 proteolysis and subcellular localization. Genes Dev 12: 3499-3511, 1998.

26. Graff JR, Konicek BW, McNulty AM, Wang Z, Houck K, Allen S, Paul JD, Hbaiu A, Goode RG, Sandusky GE, et al: Increased AKT activity contributes to prostate cancer progression by dramatically accelerating prostate tumor growth and diminishing p27 ${ }^{\mathrm{Kipl}}$ expression. J Biol Chem 275: 24500-24505, 2000.

27. $\mathrm{Xu} \mathrm{W}$, Yang $\mathrm{Z}$ and $\mathrm{Lu} \mathrm{N}$ : A new role for the PI3K/Akt signaling pathway in the epithelial-mesenchymal transition. Cell Adh Migr 9: 317-324, 2015

28. Cicatiello L, Scafoglio C, Altucci L, Cancemi M, Natoli G, Facchiano A, Iazzetti G, Calogero R, Biglia N, De Bortoli M, et al: A genomic view of estrogen actions in human breast cancer cells by expression profiling of the hormone-responsive transcriptome. J Mol Endocrinol 32: 719-775, 2004.

29. Sui G, Affar el B, Shi Y, Brignone C, Wall NR, Y in P, Donohoe M, Luke MP, Calvo D, Grossman SR, et al: Yin Yang 1 is a negative regulator of p53. Cell 117: 859-872, 2004

30. Riggs KJ, Saleque S, Wong KK, Merrell KT, Lee JS, Shi Y and Calame K: Yin-yang 1 activates the I promoter. Mol Cell Biol 13: 7487-7495, 1993.

31. Vella P, Barozzi I, Cuomo A, Bonaldi T and Pasini D: Yin Yang 1 extends the Myc-related transcription factors network in embryonic stem cells. Nucleic Acids Res 40: 3403-3418, 2012. 
32. Lu SY, Rodriguez M and Liao WS: YY1 represses rat serum amyloid A1 gene transcription and is antagonized by NF-kappa B during acute-phase response. Mol Cell Biol 14: 6253-6263, 1994

33. Sepulveda MA, Emelyanov AV and Birshtein BK: NF-kappa B and Oct-2 synergize to activate the human $3^{\prime}$ Igh hs4 enhancer in B cells. J Immunol 172: 1054-1064, 2004.

34. Wang H, Hertlein E, Bakkar N, Sun H, Acharyya S, Wang J, Carathers M, Davuluri R and Guttridge DC: NF-kappaB regulation of YY1 inhibits skeletal myogenesis through transcriptional silencing of myofibrillar genes. Mol Cell Biol 27: 4374-4387, 2007.

35. Martínez-Paniagua MA, Baritaki S, Huerta-Yepez S, OrtizNavarrete VF, González-Bonilla C, Bonavida B and Vega MI Mcl-1 and YY1 inhibition and induction of DR5 by the BH3-mimetic Obatoclax (GX15-070) contribute in the sensitization of B-NHL cells to TRAIL apoptosis. Cell Cycle 10: 2792-2805, 2011

36. Reséndiz-Martínez J, Asbun-Bojalil J, Huerta-Yepez S and Vega M: Correlation of the expression of YY1 and Fas cell surface death receptor with apoptosis of peripheral blood mononuclear cells, and the development of multiple organ dysfunction in children with sepsis. Mol Med Rep 15: 2433-2442, 2017.

37. Naruse K, Lash GE, Innes BA, Otun HA, Searle RF, Robson SC and Bulmer JN: Localization of matrix metalloproteinase (MMP)-2, MMP-9 and tissue inhibitors for MMPs (TIMPs) in uterine natural killer cells in early human pregnancy. Hum Reprod 24: 553-561, 2009.
38. Tian FJ, Cheng YX, Li XC, Wang F, Qin CM, Ma XL, Yang J and Lin Y: The YY1/MMP2 axis promotes trophoblast invasion at the maternal-fetal interface. J Pathol 239: 36-47, 2016.

39. Fabbri M, Garzon R, Cimmino A, Liu Z, Zanesi N, Callegari E, Liu S, Alder H, Costinean S, Fernandez-Cymering C, et al: MicroRNA-29 family reverts aberrant methylation in lung cancer by targeting DNA methyltransferases $3 \mathrm{~A}$ and 3B. Proc Natl Acad Sci USA 104: 15805-15810, 2007.

40. Hu Z, Cui Y, Zhou Y, Zhou K, Qiao X, Li C and Wang S: MicroRNA-29a plays a suppressive role in non-small cell lung cancer cells via targeting LASP1. Onco Targets Ther 9: 6999-7009, 2016.

This work is licensed under a Creative Commons Attribution-NonCommercial-NoDerivatives 4.0 International (CC BY-NC-ND 4.0) License. 